\title{
Expression and characterization of thermotolerant lipase with broad pH profiles isolated from an Antarctic Pseudomonas sp strain AMS3
}

\author{
Wahhida Latip ${ }^{1}$, Raja Noor Zaliha Raja Abd Rahman ${ }^{\text {Corresp., }}{ }^{1,2}$ ， Adam Leow Thean Chor ${ }^{1,3}$, Fairolniza Mohd \\ Shariff ${ }^{1,2}$, Mohd Shukuri Mohamad Ali ${ }^{1,4}$ \\ 1 Enzyme and Microbial Technology Research Center, Universiti Putra Malaysia, Serdang, Selangor, Malaysia \\ 2 \\ 3 Department of Cell and Molecular Biology, Faculty of Biotechnology and Biomolecular Sciences, Universiti Putra Malaysia, UPM Serdang, Selangor, \\ Malaysia \\ 4 Department of Biochemistry, Faculty of Biotechnology and Biomolecular Sciences, Universiti Putra Malaysia, Serdang, Selangor, Malaysia \\ Corresponding Author: Raja Noor Zaliha Raja Abd Rahman \\ Email address: rnzaliha@upm.edu.my
}

A gene encoding a thermotolerant lipase with broad $\mathrm{pH}$ was isolated from an Antarctic Pseudomonas strain AMS3. The recombinant lipase AMS3 was purified by single-step purification using affinity chromatography, yielding a purification fold of approximately 1.52 and a recovery of $50 \%$. The molecular weight was approximately $\sim 60 \mathrm{kDa}$ including the strep and affinity tags. Interestingly, the purified Antarctic AMS3 lipase exhibited broad temperature profile from $10-70{ }^{\circ} \mathrm{C}$ and stable over a broad $\mathrm{pH}$ range from 5.0 to $\mathrm{pH} 10.0$. Various mono and divalent metal ions increased the activity of the AMS3 lipase, but $\mathrm{Ni}^{2+}$ decreased its activity. The purified lipase exhibited the highest activity in the presence of sunflower oil. In addition, the enzyme activity in $25 \% \mathrm{v} / \mathrm{v}$ solvents at $50{ }^{\circ} \mathrm{C}$ particularly to n-hexane, DMSO and methanol could be useful for catalysis reaction in organic solvent and at broad temperature 
1

2

3

4

5

6

7

8

9 10

11

12

13

14

1

0

\section{Expression and characterization of thermotolerant lipase with broad pH profiles isolated from an Antarctic Pseudomonas sp strain AMS3}
Wahhida Latip ${ }^{1}$, Raja Noor Zaliha Raja Abd Rahman ${ }^{1,2^{*}}$, Adam Leow Thean Chor ${ }^{1,4}$, Fairolniza Mohd Shariff ${ }^{1,2}$, and Mohd. Shukuri Mohamad Ali ${ }^{1,3}$
${ }^{1}$ Enzyme and Microbial Technology Research Center, ${ }^{2}$ Department of Microbiology, ${ }^{3}$ Department of Cell and Molecular Biology, ${ }^{4}$ Department of Biochemistry, Faculty of Biotechnology and Biomolecular Sciences, Universiti Putra Malaysia, 43400 Serdang, Selangor, Malaysia

$$
\text { *Corresponding author: }
$$

$$
\text { Raja Noor Zaliha Raja Abd Rahman, }
$$

Department of Microbiology, Faculty of Biotechnology and Biomolecular Sciences,

Enzyme and Microbial Technology Research Center, Universiti Putra Malaysia, 43400 Serdang, Selangor, Malaysia

$$
\text { Tel: }+603-89461416
$$

$$
\text { Fax: }+603-89437590
$$

Email address: rnzaliha@upm.edu.my 
30 Abstract

31 A gene encoding a thermotolerant lipase with broad $\mathrm{pH}$ was isolated from an Antarctic

32 Pseudomonas strain AMS3. The recombinant lipase AMS3 was purified by single-step purification 33 using affinity chromatography, yielding a purification fold of approximately 1.52 and a recovery of

$3450 \%$. The molecular weight was approximately $\sim 60 \mathrm{kDa}$ including the strep and affinity tags.

35 Interestingly, the purified Antarctic AMS3 lipase exhibited broad temperature profile from $10-70{ }^{\circ} \mathrm{C}$ 36 and stable over a broad $\mathrm{pH}$ range from 5.0 to $\mathrm{pH}$ 10.0. Various mono and divalent metal ions 37 increased the activity of the AMS3 lipase, but $\mathrm{Ni}^{2+}$ decreased its activity. The purified lipase 38 exhibited the highest activity in the presence of sunflower oil. In addition, the enzyme activity in 25 $39 \% \mathrm{v} / \mathrm{v}$ solvents at $50{ }^{\circ} \mathrm{C}$ particularly to $\mathrm{n}$-hexane, DMSO and methanol could be useful for catalysis 40 reaction in organic solvent and at broad temperature

\section{$42 \quad 1.0$ Introduction}

43 Psychrophiles produce cold active enzymes, which are more active at low and moderate 44 temperatures compared to homologous mesophilic enzymes. These enzymes are capable of 45 maintaining the flexibility and dynamics of their active site at low temperatures. The enzymes are 46 highly useful in biotechnological application as they save energy costs, prevent undesired chemical 47 transformation, prevent the loss of volatile compounds and do not require expensive heating or 48 cooling systems [Margesin et al., 2003].

Lipases or triacylglycerol acylhydrolases (EC 3.1.1.3) are long chain fatty acid ester hydrolases and

51 are currently attracting enormous attention because of their biotechnological potential. Lipases

52 occur widely in nature and are largely produced by animals, plants and microbes; microbial lipases

53 are the most studied and commercialized. Microbial lipases have gained huge attention from 
54 industry because of their flexibility in temperature, $\mathrm{pH}$ and organic solvent [Verma et al., 2012].

55 Lipases have been widely used for biotechnological and industrial applications such as in the food 56 and leather industries, oil processing, environmental management and the production of 57 surfactants, detergents, and pesticides. The temperature stability of lipases has been regarded as 58 the most important characteristic for use in industry. Cold-adapted lipases are largely used in the 59 detergent industry, where cold washing reduces both energy consumption and the wear and tear of textile fibers. These lipases are also preferred in the food industry, as these enzymes can be 61 inactivated at reasonably low temperatures, thereby conserving the nutritional quality of the food. 62 Lipase specificity to catalyze triglycerides in particular has attracted application in nutraceutical 63 industry. Specific structured triacylglycerols (SSTs) [Xuebing et al., 2000] is a product from mainly 64 produced via lipase reactions in which the chemical catalysts are unable to do. They are also used in 65 environmental applications such as wastewater treatment and the bioremediation of fat66 contaminated cold environments [Lu et al., 2000].

67 Chemical processes, including biomass conversion, bioremediation and fermentation, are highly 68 desired to be completed at lower temperatures because this approach reduces the risk of 69 contamination by mesophiles and saves on energy consumption [Cotarlet et al., 2011]. In 70 conjunction with these needs, studies focused on enzymes with unique properties (i.e. broad 71 temperature and $\mathrm{pH}$ profiles) have gained an increasing interest. To the best of our knowledge, 72 there is no report pertaining to Antarctic lipases exhibiting activities at broad temperature and $\mathrm{pH}$ 73 ranges. This current work describes the gene isolation, expression, recombinant lipase purification 74 and characterization of a lipase from Antarctic Pseudomonas with broad temperature and $\mathrm{pH}$ 75 profiles. 


\section{$79 \quad 2.0$ Materials and methods}

80

81

82

83

84

85

86

87

90

91

92 rate of release one micromole of free fatty acid in one min.

\subsection{Sources of bacteria} al., 1999).

\subsection{Quantitative assay for lipase activity}

101

102

The bacterium was isolated from Antarctic soil. The isolated denoted as AMS3. Identification was performed using 16SrDNA and homology to Pseudomonas spp. The 16SrDNA sequence was sent to NCBI under accession no (KR821141). The isolate was screened to produce lipase via qualitative approach using selective media tributyrin, Rhodamine B and Victoria Blue agar plates containing tributyrin, triolen and olive oil respectively as substrate.[Samad et al., 1989]. Lipase producer will hydrolyze the lipid to free fatty acid. Lipolysis is observed directly by changes in the appearance of the substrate such as forming a clearing zone and change in colour of indicator dye used. (Scholze et

The lipase assay was performed with a colorimetric method using olive oil as the substrate as previously described by Kwon and Rhee (1986) [Kwon et al., 1986]. A reaction mixture of $1.0 \mathrm{ml}$ of enzyme, $2.5 \mathrm{ml}$ olive oil emulsion (50\% olive oil + $50 \%$ phosphate buffer, the emulsion was mix using homogenizer at $2500 \mathrm{rpm}$ ) and $0.02 \mathrm{ml} \mathrm{CaCl} 2.2 \mathrm{H}_{2} \mathrm{O}$ was used. The reaction mixture was incubated for $30 \mathrm{~min}$ with shaking ( $250 \mathrm{rpm}$ ) at $37^{\circ} \mathrm{C}$. The reaction was stopped by the addition of $5.0 \mathrm{ml}$ isooctane. The upper layer $(4.0 \mathrm{ml})$ was moved to a test tube, and $1.0 \mathrm{ml}$ of cupric acetate pyridine $\mathrm{pH} 6.1$ was added. The concentration of free fatty acid dissolved in isooctane was determined by measuring the absorbence at $715 \mathrm{~nm}$. One unit of lipase activity is defined as the 
$105 \quad 2.3$ Cloning of the lipase gene

\section{$106 \quad$ 2.3.1 Genomic library construction}

107 Pseudomonas sp. strain AMS3 genomic DNA was extracted using the Qiagen DNA Extraction kit 108 (Qiagen, Germany). Partial digestion of Pseudomonas AMS3 genomic DNA was performed using 109 Sau3A1 (Fermentas, Germany) to prepare a clonable size of genomic DNA. The plasmid was 110 digested with BamH1 to generate compatible ends for ligation with Sau3A1 partially digested 111 genomic DNA. The plasmid DNA $(50 \mu \mathrm{l})$ was digested with BamH1 for $1 \mathrm{~h}$ in a $100 \mu \mathrm{l}$ reaction 112 mixture that included the following components: (1) distilled water (37 $\mu$ l), (2) 10X buffer E (10 113 mM Tris-HCl, pH 7.4, $300 \mathrm{mM} \mathrm{KCl}$, and $5 \mathrm{mM} \mathrm{MgCl}_{2,}$ ) (3) $0.1 \mathrm{mM}$ Dithiothreitol (DTT) (10 $\mu$ ), (40

114 BSA (0.1 $\mu \mathrm{g} ; 1 \mu \mathrm{l}),(5)$ DNA (50 $\mu \mathrm{g})$, and (6) enzyme (10U; $2 \mu \mathrm{l})$. The mixture was incubated at $37^{\circ} \mathrm{C}$ 115 for $1 \mathrm{~h}$. The cleaved products were dephosphorylated by the direct addition of calf intestinal 116 alkaline phosphatase $(1 \mathrm{U}, 1 \mu \mathrm{l})$ for $1 \mathrm{~h}$ at $37^{\circ} \mathrm{C}$. The enzyme was deactivated by heating at $65^{\circ} \mathrm{C}$ for $11720 \mathrm{~min}$ in the presence of EDTA (5 mM). The Sau3A1 partially digested genomic DNAs with 118 maximum sizes in the range of $2-9 \mathrm{~kb}$ were ligated with the $\mathrm{pET} 51 \mathrm{~b}$ vector (BamH1 digested and 119 dephosphorylated).

120

\section{$121 \quad$ 2.3.2 Screening for positive recombinant clones}

122 Putative lipase activity was indicated by the formation of halos around the colonies on tributyrin123 ampicillin agar. Cold active lipase activity was confirmed by incubating the plates at $37^{\circ} \mathrm{C}$ for $16 \mathrm{~h}$ 124 followed by another $72 \mathrm{~h}$ of incubation at $4{ }^{\circ} \mathrm{C}$. Colonies that produced clearing zones on tributyrin125 ampicillin agar were isolated and restreaked on Victoria Blue agar and Rhodamine B agar plates to 126 confirm lipase activity. 


\section{$129 \quad$ 2.3.3 Gene sequencing}

130 Plasmid from positive transformant was extracted and digested with the BamH1. The insert was

131 predicted around $9 \mathrm{~kb}$. The T7 promoter and terminator was use to sequence the gene via primer

132 walking. Result from the starting primer was sent to 1st BASE Laboratories Sdn Bhd (Shah Alam,

133 Selangor, Malaysia) for primer walking. The primer was designed base on each sequencing result.

\subsubsection{Analysis of the lipase gene}

136 Lipase sequence analysis was performed using the National Centre of Biotechnology (NCBI) 137 database. Analysis of the lipase gene was performed using Biology Workbench 138 (http://www.biology.ncsa.sdsc.edu) and the Expasy Molecular Biology Server 139 (http://www.expacy.org/tools). The nucleotide sequence of the lipase gene has been submitted to 140 the Genbank database with the accession number KP744536 and KT215165.

\subsubsection{Expression of recombinant lipase in E. coli}

143 A cultured derived from a colony harboring the putative lipase gene (E. coli BL21/pETlipAMS3) was

144 cultured in LB media containing $50 \mathrm{mg} / \mathrm{L}$ ampicillin. A total of $200 \mathrm{ml}$ of LB media was inoculated 145 with transformed cells or empty vector and incubated at $37{ }^{\circ} \mathrm{C}$ with shaking at $150 \mathrm{rpm}$. A total of $1460.5 \mathrm{mM}$ of IPTG was added to cultures with an $\mathrm{A}_{600}$ of $0.5-0.7$ and the cells were grown at $20^{\circ} \mathrm{C}$ for 8

147 h. Cell growth was measured spectrophotometrically at $A_{600}$.

\section{$149 \quad 2.4$ Recombinant AMS3 lipase purification}

150 The His-tagged recombinant AMS3 lipase was purified using Nickel Sepharose affinity 151 chromatography. The cell pellet was resuspended using $100 \mathrm{mM}$ Tris-HCl (pH 7.4) binding buffer 152 containing $20 \mathrm{mM}$ imidazole and $0.5 \mathrm{M} \mathrm{NaCl}$. The sonicated cells were centrifuged at $12,000 \mathrm{xg}$ for 
$15330 \mathrm{~min}$ to separate the crude extract. The crude enzyme was filtered and subjected to affinity

154 columns that were pre-equilibrated with binding buffer. The recombinant enzyme was eluted using 155 elution buffer containing $100 \mathrm{mM}$ Tris- $\mathrm{HCl}$ with $0.5 \mathrm{M}$ imidazole and $0.5 \mathrm{M} \mathrm{NaCl}(\mathrm{pH} 7.4$ ). The active

156 fractions were pooled together and the protein homogeneity was determined using SDS-PAGE.

157

158

\subsection{Protein determination}

159 The protein content was measured by the Bradford method [Bradford et al., 1976]; BSA was used as 160 a standard. During chromatography, the protein concentrations in the fractions were monitored by 161 measuring the absorbance at $280 \mathrm{~nm}$.

162

\section{$163 \quad 2.6$ SDS-PAGE analysis}

164 The purified fractions that showed lipase activity were pooled and subjected to SDS-PAGE 165 according to the method described by Laemmli (1970) [Laemmli et al., 1970]. The sample was electrophoresed on a $12 \%$ resolving gel $(2.5 \mathrm{ml} 1.5 \mathrm{M}$ Tris-HCl (pH 8.8), $100 \mu \mathrm{l} 10 \%$ SDS, $4.4 \mathrm{ml}$ distilled water, $3 \mathrm{ml}$ Bis-acrylamide (12\%), $50 \mu \mathrm{l}$ APS and $10 \mu \mathrm{l}$ TEMED) and a $6 \%$ stacking gel (2.5 ml 0.5 M Tris-HCl (pH 6.8), $100 \mu \mathrm{l} 10 \%$ SDS, 5.9 ml distilled water, 1.5 ml $12 \%$ Bis-acrylamide and $50 \mu \mathrm{l}$ APS). Electrophoresis was performed at a constant voltage $(210 \mathrm{~V})$ at room temperature. Coomassie Brilliant Blue R 250 was used to stain the gel for $10 \mathrm{~min}$, and then the gel was destained

171 with destaining solution. The molecular mass of the protein was estimated using a protein standard 172 marker (Unstained protein marker from Thermo scientific U.S.A).

173

174

175

2.7 Characterization of AMS3 lipase

176

\section{$177 \quad$ 2.7.1 Effect of temperature}


178 The effect of temperature on the recombinant lipase was studied by measuring the enzyme activity 179 at varying temperatures $\left(5{ }^{\circ} \mathrm{C}, 10^{\circ} \mathrm{C}, 20^{\circ} \mathrm{C}, 30^{\circ} \mathrm{C}, 40{ }^{\circ} \mathrm{C}, 50^{\circ} \mathrm{C}, 60^{\circ} \mathrm{C}\right.$ and $\left.70{ }^{\circ} \mathrm{C}\right)$ for $30 \mathrm{~min}$ at $\mathrm{pH} 7$. 180 The activity was assayed following the method of Kwon and Rhee (1986) and the assay was done 181 using olive oil as substrate. To assess the effect of temperature on the thermostability of the lipase, 182 the enzyme solution was pre-incubated in $50 \mathrm{mM}$ Phosphate buffer (pH 7) at different 183 temperatures $\left(5^{\circ} \mathrm{C}, 10^{\circ} \mathrm{C}, 20^{\circ} \mathrm{C}, 30^{\circ} \mathrm{C}, 40{ }^{\circ} \mathrm{C}, 50{ }^{\circ} \mathrm{C}, 60^{\circ} \mathrm{C}\right.$ and $\left.70{ }^{\circ} \mathrm{C}\right)$ for $30 \mathrm{~min}$ and assayed at the 184 optimum temperature.

185

\section{$186 \quad$ 2.7.2 Effect of pH.}

187 The optimum $\mathrm{pH}$ of the recombinant lipase was studied by emulsifying the substrate (olive oil) in 188 buffers of different $\mathrm{pH}$ values (4.0-12.0). The following buffers (50 mM) were used: (1) sodium 189 acetate (pH 4.0-6.0), (2) potassium phosphate ( $\mathrm{pH} 6.0-8.0$ ), (3) Tris- $\mathrm{HCl}(\mathrm{pH}$ 8.0-9.0) and (4) 190 glycine- $\mathrm{NaOH}(\mathrm{pH} 9.0-12.0)$. To assess the $\mathrm{pH}$ stability of the lipase, the enzyme solution was pre191 incubated in different $\mathrm{pH}$ buffers ( $\mathrm{pH} 4.0-12.0$ ) at $50^{\circ} \mathrm{C}$ for $30 \mathrm{~min}$, followed by the lipase assay.

192

\section{$193 \quad$ 2.7.3 Effect of metal ions}

194 The effect of metal ions on lipase activity was studied using the method described by Kwon and 195 Rhee (1986) after the enzyme was pre-incubated at $50{ }^{\circ} \mathrm{C}$ for $30 \mathrm{~min}$ in $50 \mathrm{mM}$ Phosphate buffer 196 (pH 8.0) and either $1 \mathrm{mM}$ or $5 \mathrm{mM}$ of various metal ions in different reaction vessels $\left(\mathrm{Li}^{+}, \mathrm{Rb}^{+}, \mathrm{Na}^{+}\right.$, 197 $\mathrm{Mg}^{2+}, \mathrm{Ca}^{2+}, \mathrm{Fe}^{2+}, \mathrm{Mn}^{2+}, \mathrm{K}^{+}, \mathrm{Zn}^{2+}, \mathrm{Ni}^{2+}$ or $\left.\mathrm{Co}^{2+}\right)$.

198

199

\subsubsection{Natural oil specificity}

200 Natural oils (olive oil, corn oil, sun flower oil, canola oil, sesame oil, coconut oil and palm oil) were 201 tested for AMS3 lipase activity. The oils were assayed at $50{ }^{\circ} \mathrm{C}$ for 30 min colorimetrically. 
205

206

207

208

209

210

211

212

213

214

215

216

217

218

219

220

221

222

223

224

225

226

227

\subsubsection{Effect of organic solvents}

The effects of organic solvents on lipase activity were determined by measuring the residual activity after pre-incubation of the enzyme with different solvents at a concentration of $25 \%(\mathrm{v} / \mathrm{v})$ in $50 \mathrm{mM}$ Phosphate buffer ( $\mathrm{pH} 8.0$ ) at $50{ }^{\circ} \mathrm{C}$ for $30 \mathrm{~min}$. The residual activity was measured following the method of Kwon and Rhee (1986) and using olive oil as a substrate. The solvents used had varying $\log P$ values as shown in parenthesis. The following solvents were used: (1) DMSO (1.45), (2) methanol (-0.76), (3) acetonitrile (-0.33), (4) ethanol (-0.24), (5) acetone (-0.24), propanol (0.28), (6) chloroform (2.0), (7) benzene (2.0), (8) toluene (2.5), (9) xylene (3.1) and (10) n-hexane (3.5).

\subsubsection{Statistical analysis}

The standard deviations of the triplicate data were performed using deviation (SD) in Microsoft office excel 2010 (Microsoft Corporation USA). The data are mean \pm standard deviation of three determinations and indicated as error bars. When the error bar cannot see seen, they are less than the size of symbol.

\subsection{Secondary structure and thermal denaturation measurement of AMS3 lipase using} Circular dichroism (CD) spectropolarimeter

Circular dichroism (CD) spectra were recorded using JASCO J-810 spectropolarimeter at $25^{\circ} \mathrm{C}$. The purified AMS3 lipase was dialysed over night with $10 \mathrm{mM}$ phosphate buffer $\mathrm{pH} 7$ prior to CD spectral analysis. The secondary content measurement was conducted from wavelength of 190 to $260 \mathrm{~nm}$ on a $1 \mathrm{~mm}$ path length. A few temperatures have been set to measure the changes of 
228 secondary structure from $10{ }^{\circ} \mathrm{C}$ to $90{ }^{\circ} \mathrm{C}$. The protein concentration was $0.1 \mathrm{mg} / \mathrm{ml}$ and the cell 229 pathlength $0.1 \mathrm{~cm}$. The data been collected every $1 \mathrm{~nm}$ (band with) and the data pitch every $0.5 \mathrm{~nm}$. 230 Protein secondary structures content were estimated from the far-UV CD spectra based on 231 webserver, perry.freeshell.org [Raussens et al., 2003]

232

233 The thermal denaturation of AMS3 lipase was measured at $222 \mathrm{~nm}$ from $10{ }^{\circ} \mathrm{C}$ to $90{ }^{\circ} \mathrm{C}$ at a 1 $234{ }^{\circ} \mathrm{C} / \mathrm{min}$ heating rate. Wavelengths $222 \mathrm{~nm}$ measures $\alpha$-helical content of the protein. Data collected 235 from higher wavelengths usually have lower absorption. $T_{\mathrm{m}}$ is defined as a midpoint of sigmoidal 236 melting curves using $0.5 \mathrm{mg} / \mathrm{ml}$ protein. The data was collected every 1 degree per min. Data pitch, 237 bandwidth, response, scanning speed, and accumulation were set to be 0.1 degree, $1 \mathrm{~nm}, 1$ seconds, 2381 degree per min and 3 times, respectively.

\subsection{Results and discussion}

\section{$242 \quad 3.1$ Lipase gene isolation and expression in E. coli}

243 To isolate the lipase gene, a genomic library approach was completed. To achieve this, a library was

244 constructed via fragmentation or partial digestion of genomic DNA using Sau3A1. The plasmid 245 (pET51b) was linearized using BamHI. Among thousands of transformants from the shotgun 246 cloning, three of them produced a clearing zone. The positive recombinants harboring the putative 247 lipase gene were assumed to have cold active lipolytic activity when the recombinant clone was 248 initially grown at $37{ }^{\circ} \mathrm{C}$ for $24 \mathrm{~h}$ and transferred at $4{ }^{\circ} \mathrm{C}$. The clearing zone only appeared after 3 249 days of incubation at $4{ }^{\circ} \mathrm{C}$. The colonies were transferred to two selective media plates, triolein and 250 Rhodamine B plates, to confirm lipase gene expression. Colonies 1 and 2 gave a positive result by 251 the intense blue and orange coloration around the colonies. Colony 3, however, did not exhibit such 252 coloration. These results show that these two colonies produced a putative true lipase compared to 
253 colony 3 that was a putative esterase producer (data shown at supporting document). To identify a

254 true lipase producer the transformant must able to hydrolyse triglyceride that contain long chain

255 fatty acid (Scholze et al., 1999). Colony 1 and 2 were sent for sequencing and the partial sequence

256 from both colonies shown to contain putative gene from $\alpha / \beta$ hydrolase family. Colony 1 (denoted as

257 AMS3 lipase) was selected due to the high catalytic activity at $20^{\circ} \mathrm{C}$ and was used for the remainder

258 of the study.

259 Generally, protein functional and structural studies often require a large amount of pure, correctly 260 folded protein, which is commonly produced in Escherichia coli expression systems. However, these 261 overexpressed proteins are sometimes not efficiently processed by the E. coli post-translational 262 machinery, resulting in protein misfolding. A dense insoluble aggregate of misfolded proteins is 263 generally known as inclusion bodies (IBs). Most of the lipases from Pseudomonas are expressed in 264 the form of IBs. Even under the control of pET-25b(+), a vector containing a signal sequence 265 responsible for the translocation of expressed protein to the periplasm, the lipases from 266 Pseudomonas sp. MIS38 and Pseudomonas sp. strain KB700A were still overexpressed in non-active, 267 insoluble forms [Claudia et al., 2009 and Rashid et al., 2001]

268

269

270

271

272

273

274

275

\subsection{Lipase sequence analysis}

Putative plasmid contained recombinant lipase AMS3 was sent for sequencing. A few sets of primer were used to complete the sequence. The presence for open reading frame (ORFs) was analyzed using the ORF finder software from the NCBI. One open reading frame (ORF) was found. With a predicted size of 1353 bp encoding a 450 amino acid was determined. The protein sequence is made up by two different domains namely the GST C (KT215165) domain and lipase (KP744536) domain at the $\mathrm{N}$ and $\mathrm{C}$ terminal sections respectively. The lipase (AMS3 lipase) molecular mass without the GST C sequence was predicted to be $43.6 \mathrm{kDa}$ with pI value of 6.3 . The BLASTp result revealed that AMS3 lipase showed homology to $\alpha / \beta$ hydrolase family. Multiple sequence alignment 
279 was done using Biology Workbench software to predict the conserve region of the lipase. Aligment

280 between known lipase from various microorganisms exhibited the conserved region of the lipase

281 (Fig 1). A typical lipase conserved region contains the pentapeptide (GXSXG) sequence. The lipase

282 catalytic triad which made up by Ser, Asp and His were also conserved. No signal peptide sequence

283 was observed as predicted using SignalP software. Similarly, Group III lipases including lipases

284 from Pseudomonas fluorescens and Serratia marcescens has no signal peptide. The protein origin can

285 be reveal from $\mathrm{G}+\mathrm{C}$ content. The $\mathrm{G}+\mathrm{C}$ content was calculated using http: www.watson.nih.go.jp

286 (FramePlot 2.3.2). AMS3 lipase content $55 \%$ of $\mathrm{G}+\mathrm{C}$ almost similar to lipase from Pseudomonas

287 fragi (59.3\%) [Claudia et al., 2009]. The $\mathrm{N}$ terminal section of AMS3 lipase contains a GST C

288 (glutathione-S-transferase C family) similar to Pseudomonas Ag1. Glutathione have been reported

289 as essential factor for chaperon to activate the lipase from Pseudomonas.[ Rosenau et al., 2000 and

290 Tanaka et al., 2000]. According to Tanaka and co-workers, glutathione was found to be important

291 for 'lipase activator factor' or Lif protein from Pseudomonas sp. strain 109 to fold an active form

292 [Tanaka et al., 2000].

293

294

295

296

297

298

299

300

301

302

303

304

Fig 1: Alignment of the AMS3 lipase sequence with Pseudomonas lipases of known threedimensional structure. The AMS3 was aligned with $P$. aeruginosa lipase (Q9L6C7), $P$. fragi lipase (AY787823), G. bacillus T1 (AY166603) and Proteus sp. K107. - =Serine Pentapeptide, @= Aspartic acid and ${ }^{\wedge}=$ Amino acid involve in calcium binding. $\left({ }^{*}\right)$ blue: Conserved residue; (:) green: conservation of strong groups; (.) blue: conservation of weak groups.

\subsection{Purification of AMS3 lipase}

E. coli BL21 cells (DE3) harboring the pET51b/lipAMS3 plasmid was used to overexpress the 306 recombinant AMS3 lipase under the control of a T7 promoter. The crude AMS3 lipase containing 
307 10x histidine and Strep tags was produced in a soluble form allowing for rapid purification of the

308 recombinant protein. The addition of fusion affinity tags and GST C Pseudomonas A3 increased the

309 size of AMS3 lipase to $\sim 60 \mathrm{kDa}$. Purification was accomplished using the XK16 affinity

310 chromatography column (GE Healthcare, USA) packed with Nickel Sepharose resin. After the

311 column was equilibrated with binding buffer, the crude sample was loaded onto the column. Elution

312 was accomplished using increasing concentrations of imidazole. Pooled fractions resulted in a $50 \%$

313 yield. Some protein was retained in the low-yield fractions and not included in the pooled fraction,

314 resulting in some loss. Pooled fractions had an overall purification factor of approximately 1.52 fold.

315 In 2007, Yan et al. reported that their organic solvent-stable and thermostable lipase from

316 Galactomyces geotrichum Y05 had up to a $32 \%$ recovery and a 3.2-fold purification factor using

317 ammonium sulfate, an ion exchange column and gel filtration purification [Yan et al., 2007]. SDS-

318 PAGE analysis indicated that the molecular weight of the AMS3 lipase was approximately $\sim 60 \mathrm{kDa}$

319 (Fig. 2). Generally, lipases have molecular weights in the range of 16 to $69 \mathrm{kDa}$. According to

320 Schmidt-Dannert (1999), the Staphylococcal lipase family, which includes lipase BTL-2 from B.

321 thermocatenulatus, possesses molecular weights of 40 to $45 \mathrm{kDa}$ [Schmidt-Dannert 1999].

322

323

324

325

326

327

328

329

330

331

\section{3.4 Biochemical Characteristics of AMS3 lipase}

\section{$333 \quad$ 3.4.1 Effect of temperature.}


334 Lipase activity was determined from 5 to $70^{\circ} \mathrm{C}$. The optimum temperature for the lipase was 335 activity was at $50{ }^{\circ} \mathrm{C}$, and the activity dropped above $60{ }^{\circ} \mathrm{C}$ (Fig. 3A). Interestingly, the purified

336 lipase exhibited a broad temperature profile, whereby the lipase was still active at temperatures 337 ranging from $10-60{ }^{\circ} \mathrm{C}$. This finding is unlike the typical characteristics of cold active lipase. Most 338 cold active lipases have been found to be active at temperature ranges from $15-35{ }^{\circ} \mathrm{C}$ [Gerday et al., 339 2000]. Few "however" have reported the broad temperature observation from 340 psychrophilic/psychrotolerant bacteria. A Pseudomonas lipase from Greenland exhibited an almost 341 similar activity at wide temperatures [Schmidt et al., 2010]. In contrast, AMS3 lipase exhibited 342 higher optimum activity compared to other reported lipases isolated from psychrophilic bacteria. r343 LipA from Sorangium cellulosum [Cheng et al., 2011], lipA1 from Psychrobacter sp. 7195 [Zhang et 344 al., 2009], lipase from Pseudomonas fragi strain IFO 3458 (PFL) [Alquati et al., 2002] and lipX from 345 Psychrobacter sp. C18 [Alquati et al., 2011] were all reported to show maximum activity at $30{ }^{\circ} \mathrm{C}$. 346 AMS3 lipase was mostly stable at $30^{\circ} \mathrm{C}$ and below (Fig. 3B). The organic solvent-stable and

347 thermostable lipase from Galactomyces geotrichum Y05 was stable below $60{ }^{\circ} \mathrm{C}$ at a pH of 8.0 for at 348 least $12 \mathrm{~h}$; however, above $60^{\circ} \mathrm{C}$, rapid inactivation occurred with only $36 \%$ residual activity. 349 These characteristics differ from those of the AMS3 lipase and may be due to the effects of the 350 nature of the enzyme itself, which originated from Antarctica.

Fig 3: Effect of temperature on purified AMS3 lipase activity. The lipase assay was done using olive oil as a substrate. (A). Enzyme samples were assayed at various temperatures as mentioned in the Methods section. The temperature that showed the highest lipase activity was considered to be the optimum temperature for the AMS3 lipase. The effect of temperature on purified AMS3 lipase stability (B). Enzyme stability was tested at different temperature. The enzyme was incubated at various temperatures in $30 \mathrm{~min}$. The assay was performed at optimum temperature. The relative activity was calculated using $30^{\circ} \mathrm{C}$ as $100 \%$. 


\subsubsection{Effect of pH}

366

367

368

369

370

371

372

373

374

375

376

377

378

379

380

381

382

383

384

385

386

387

388

The broad temperature range of AMS3 lipase showed activity in the pH range from 5.0 to 10.0; the optimum activity was seen at pH 8.0 (Fig. 4A). Lipase activity was reduced above a pH of 8.0, with a relative activity of $34 \%$ at pH 9.0. Most of the studied Pseudomonas lipases have been known to be active around $\mathrm{pH} 7$ to 8 , stable at $\mathrm{pH}$ ranging from 6 to 9 . To date, only a few lipases reported an optimum activity at pH 9 to 10. The cold-adapted lipase from Psychrobacter sp. 7195 [Zhang et al., 2007] and a mesophilic lipase from Pseudomonas fluorescens JCM5963 [Zhang et al., 2009] reported an optimum activity at $\mathrm{pH}$ 9, "whereas" lipases from Acinetobacter sp. XMZ-26 (cold-adapted) [Zheng et al., 2011] and Pseudomonas fluorescens AK102 [Kojima et al., 2003] reported an optimum activity at $\mathrm{pH} 10$. The AMS3 lipase was stable from pH 5.0 to 10.0 after incubation for 30 min at 50 ${ }^{\circ} \mathrm{C}$ (Fig. 4B). Extracellular lipase from Thermomyces lanuginosus was also reported to be stable at in broad range alkaline $\mathrm{pH}$ from $\mathrm{pH}$ 8-12 [Zheng et al., 2011]. In contrast with AMS3 lipase the enzyme was stable from acidic to alkaline condition. These properties make the enzyme more valuable in detergent and oleochemical industries. Enzymes are proteinaceous, meaning that they have amino acids whose ionization can be affected by $\mathrm{pH}$. The primary and secondary structures of the enzymes can be affected, thereby affecting the activity. The primary and secondary structures of the AMS3 lipase may be influencing these $\mathrm{pH}$ and temperature stabilities, leading to the variation in the ionization of the native AMS3 lipase enzyme at different $\mathrm{pH}$.

Fig 4: Effect of $\mathrm{pH}$ on purified AMS3 lipase activity (A). The lipase activity was measured at different $\mathrm{pH}$ using olive oil emulsion as substrate and assay at $50{ }^{\circ} \mathrm{C}$ for $30 \mathrm{~min}$. Effect of $\mathrm{pH}$ on purified AMS3 lipase stability is shown in figure (B). The enzyme was pre-incubated at different buffer for $30 \mathrm{~min}$. The lipase assay was performed at $50{ }^{\circ} \mathrm{C}$. Sodium acetate buffer was used for the 
389

390

391

392

393

394

395

396

397

398

399

400

401

402

403

404

405

406

407

408

409

410

411

412

413

414

415

416

417
pH range of 4.0 to $6.0(\diamond)$; potassium phosphate buffer for the pH range of 6.0 to 8.0 ( $\square$ ); Tris-HCl buffer for the $\mathrm{pH}$ range of 8.0 to $9.0(\boldsymbol{\Delta})$; and glycine- $\mathrm{NaOH}$ buffer for the $\mathrm{pH}$ range of 9.0 to 12.0. (x). The relative activity was measure using $\mathrm{pH} 7$ as $100 \%$.

\subsubsection{Effect of metal ions}

The effect of metal ions was studied to determine which metal ions could enhance or reduce the activity of AMS3 lipase. All of the metal ions studied enhanced lipase activity at 1 and 5 mM (Fig. 5).

For $\mathrm{Li}^{+}$and $\mathrm{Rb}^{+}$lipase activity was heavily enhanced, with relative activities over then $160 \% . \mathrm{Li}^{+}$ have been reported to improve the enantioselectivity of the lipase (Okamoto et al., 2006). $\mathrm{Na}^{+}$and $\mathrm{K}^{+}$were also found to enhance AMS3 lipase activity. Metal ion activation of enzymes is important in industrial applications for obtaining maximal catalytic efficiency. However, at $5 \mathrm{mM}$ concentration, $\mathrm{Li}^{+}, \mathrm{Ni}^{2+}$ and $\mathrm{Zn}^{2+}$ reduced lipase activity to less than $50 \%$. In contrast, Sharma et al. (2002) reported that $\mathrm{Ca}^{2+}$ ions increased the lipase activity of Bacillus sp. RSJ-1 by $16 \%$, similar to the lipase activity of B. coagulans MTCC-6375 [Sharma et al., 2002].

Fig 5: Effect of metal ions on AMS3 lipase stability. All assay was done using olive oil as substrate. The enzyme was pre-incubated at $50^{\circ} \mathrm{C}$ with various metal ions at concentrations of $1 \mathrm{mM}$ (blue) and $5 \mathrm{mM}$ (red). The treated enzyme was assay at $50{ }^{\circ} \mathrm{C}$ for $30 \mathrm{~min}$. The untreated enzyme was considered as a control or $100 \%$.

\subsubsection{Substrate specificity.}

Assays addressing the specificity of the AMS3 lipase towards natural oils were conducted. The results showed that the AMS3 lipase hydrolyzed all of the natural oils tested, and the highest activity was seen with sunflower oil (Fig. 6). Olive oil is composed of mixed triglycerides 
418 (monounsaturated C18:1). Most lipases show a preference for long-chain fatty acids. The

419 extracellular lipase Lip2 from Yarrowia lipolytica showed a much higher lipolytic activity toward

420 triglycerides in olive oil and safflower oil than toward hydrophilic esters such as methyl fatty acid

421 asters [Jaeger et al., 1999].

422

423 The AMS3 lipase displayed the second highest activity with coconut oil, with a relative activity of

$424110 \%$, followed by canola oil, olive oil and sesame oil with relative activities of $106 \%, 100 \%$ and

$42590 \%$, respectively. Similarly, AMS3 lipase exhibited the same substrate specificity with an

426 extracellular lipase from Pseudomonas sp S5 [Rahman et al., 2005]. In contrast, a Pseudomonas

427 aeruginosa EF2 lipase reported olive oil as its preferred substrate [Gilbert et al., 1991]. AMS3 lipase

428 has a broader substrate specificity ranging from C12 to C18. The ability of AMS3 lipase to hydrolyze

429 long carbon chain triglycerides (C12 above) showed that the enzyme is a true lipase (Jaeger, et al.,

430 1994). According to Jaeger et al. (1994), surface pressure and lipid distribution are physical factors

431 that can impact the determinants of lipase activity [Hiol et al., 1999]. Therefore, as reported by Hiol

432 et al. (1999), the differences in substrate specificity can arise not only from specific substrate

433 binding but also from differential activation of the enzyme at the interface [Lanser et al., 2001].

434

435

436

Fig 6: Substrate specificity of purified AMS3 lipase toward natural oil. The assay was performed at $50{ }^{\circ} \mathrm{C}$ for $30 \mathrm{~min}$. Substrate emulsion prepared with various natural oil with ratio 1:1 (buffer and natural oil). Data shown are the means from triplicate measurements expressing \% activity relative to that with olive oil.

440

441

442

\subsubsection{Effect of organic solvents}

443 Persson et al., (2002) reported that the use of organic solvents in enzymatic catalysis is now well

444 recognized with several advantages in water-poor mediums including improved solubility of 
445 hydrophobic substrates, a shift in thermodynamic equilibrium to synthesis from hydrolysis and

446 increased thermostability of the enzyme [Persson et al., 2002]. Assays measuring the effects of

447 solvents were conducted to understand AMS3 lipase activity in organic solvents. The enzyme was

448 incubated in a $25 \% \mathrm{v} / \mathrm{v}$ solvent at a temperature of $50{ }^{\circ} \mathrm{C}$ (Fig. 7). The results showed that AMS3

449 lipase exhibited some enhancements in stability expressed as relative activity in $25 \% \mathrm{v} / \mathrm{v}$ solvent

450 compared to the control (without solvent). For instance, AMS3 lipase has a relative activity of $74 \%$,

$45189 \%$ and $116 \%$ in DMSO, methanol and n-hexane, respectively, compared with its original activity

452 at a temperature of $50{ }^{\circ} \mathrm{C}$. The stability in the said organic solvents makes AMS3 lipase a good

453 candidate for synthesis of biodiesel and transesterification reactions. Lipases have a sheath of

454 water molecules tightly bound to them. This sheath protects the enzyme's hydrophilic surface and

455 possibly retains the native conformation even in non-polar solvents. Moreover, the changes in

456 enzyme stability in organic solvents are also greatly affected by the structure of the enzymes

457 (Gomez-puyou., 1992).

458

459

Fig 7: Effect of solvents on purified AMS3 lipase. All the assay was done using olive oil as a 461 substrate. Incubation time for treated enzyme with organic solvent was 30 min and assay at $50{ }^{\circ} \mathrm{C}$. Remaining lipase activity was expressed relative to that of the control (without solvent). Log $\mathrm{P}$ 463 (water/octanol coefficient) value of each solvents are represented in parenthesis.

464

465

466

\subsection{Secondary structure analysis of AMS3 lipase}

467

As illustrated in Fig. 8A, the resulting denaturation (sigmoidal graph shape) curve indicated a 468 structural transition of AMS3 lipase within the tested temperature range. The $\mathrm{T}_{\mathrm{m}}$ value for AMS3 lipase for this transition was $62^{\circ} \mathrm{C}$ (Fig. 8A). The Tm measurement using circular dichroism is close to the AMS3 lipase deactivation profile, which was at $55^{\circ} \mathrm{C} . \mathrm{CD}$ measurements have been widely

471 used to follow the equilibrium between helical structures and unordered conformations. The CD 
472 spectra (molecular ellipticity) of AMS3 lipase was analyzed as a function of temperature between 473190 and $260 \mathrm{~nm}$. The wavelength $220 \mathrm{~nm}$ was set to monitor the transition of $\alpha$-helical to

474 unordered structures as they exhibited characteristic signals at this wavelength. The high-tension 475 voltage (HT) value gradually increased until the $\mathrm{T}_{\mathrm{m}}$ of AMS3 lipase and then decreased as the lipase 476 unfolded above the melting temperature point. This outcome might be due to loss of protein 477 secondary structure, followed by an increase in unordered conformations. This observation was 478 supported by the secondary structure content determination at different temperatures. As depicted 479 in Fig. 8B, the increased formation of loop structures or disordered regions were observed notably 480 at temperatures from $50-90{ }^{\circ} \mathrm{C}$. In fact, AMS3 lipase exhibited a decreasing content of the alpha 481 helices. This behavior could turn out to be the deactivation factor for AMS3 lipase. The enzyme 482 gradually lost its activity beyond $50{ }^{\circ} \mathrm{C}$. The random secondary structure conformation appears to 483 be increasing as temperature drops together with $\beta$-pleat contents. The increased loop 484 confirmation was found to be one of the factors for enzymes to work at low temperatures [Amico et 485 al., 2002]. These findings could explain the AMS3 lipase broad temperature profile.

Fig 8: AMS3 lipase melting point and secondary content determination. Vertical line (arrow) indicating the melting point value of AMS3 lipase when tested from temperature ranging from 10$90{ }^{\circ} \mathrm{C}$. (Figure 8A). Changes on the secondary structure content of AMS3 lipase were notably observed as the enzyme was subjected at different temperature (Figure 8B)

\subsection{Conclusion}

495 The AMS3 lipase was successfully purified via single-step affinity chromatography. The purified 496 AMS3 lipase exhibited optimum lipolytic activity at pH 8 with a broad temperature profile from 10$49770{ }^{\circ} \mathrm{C}$ which is unique for an enzyme isolated from Antarctic microorganism. In addition, the 498 enzyme had shown to be stable when treated with different buffer condition ranging from pH 5-10. 
499 This factor will make the enzyme very useful for detergent industry. As shown with other lipases,

500 the AMS3 lipase efficiently hydrolyzed unsaturated fatty acids and sunflower oil with the highest

501 activity. Various divalent and monovalent metal ions increased the catalytic activity of the AMS3

502 lipase, but $\mathrm{Ni}^{2+}$ completely decreased its activity. Additionally, the AMS3 lipase exhibited stability in $50325 \% \mathrm{v} / \mathrm{v}$ of $\mathrm{n}$-hexane, methanol and DMSO at $50{ }^{\circ} \mathrm{C}$. These unique properties are believed to 504 provide tremendous economic benefits in pharmaceuticals, cosmetics and synthesis of functional 505 lipids as well as other low-high temperature industrial applications.

506

507

\section{$508 \quad 5.0$ References}

509 1. Alquati, C., Gioia, L.D., Santarossa, G., Alberghina, L., Fantucci, P., Lotti, M., 2002. The cold-active 510

511

512

513

514

515

516

517

518

519

520

521

522

523

524

525

526

527

528

529

530

531

532

533

534

535

536 lipase of Pseudomonas fragi. Eur J Biochem. 269: 3321-3328

2. Amico, S.D., Claverie, P., Collins, T., Georlette, D., Gratia, E., Hoyoux, A., Meuwis, M.A., Feller, Gerday, C., 2002. Molecular basis of cold adaptation. Philos T R Soc B. 357: 917-925

3. Bradford, M. M. 1976. A rapid and sensitive method for the quantitation of microgram quantities of protein using the principle of protein-dye binding. Anal Biochem. 72: 248-254

4. Chen, R., Guo, L., Dang, H., 2011. Gene cloning, expression, and characterization of a cold-adapted lipase from a psychrophilic deep-sea bacterium Psychrobacter sp. C18. World J Micro Biot. 27: 431441

5. Cheng, Y.Y., Qian, Y., Li, Z.F., Wu, Z.H., Liu, H., Li, Y.Z., 2011. A novel cold-adapted lipase from Sorangium cellulosum strain So0157-2: Gene cloning, expression and enzymatic characterization.Int J Mol Sci. 12: 6765-6780

6. Claudia, A., Luca, D.G., Gianluca, S., Lilia, A., Piercarlo, F., Marina, L.,2009 The cold-active lipase of Pseudomonas fragi Heterologous expression, biochemical characterization and molecular modeling. Eur J Biochem. 269,13:3321-3328,

7. Cotarlet, M., and Bahrim, G.E., 2011. Optimization of cold-adapted amylases and protease production by psychrotrophic Streptomyces 4 Alga using response surface methodology. Truk J Biochem. 36(2): 83-92

8. Gilbert, E. J., Cornish, A., Jones, C. W. 1991. Purification and properties of extracellular lipase from Pseudomonas aeruginosa EF2. J Gen Microbiol. (1991), 137, 2223-2229. 
537 9. Gerday, C., Aittaleb, M., Bentahir, M., Chessa, J.P., Claverie, P., Collins, T., Amico, D.S., Dumont, J., 538 Garsoux, G., Georlette, D., 2000. Cold-adapted enzymes: From fundamentals to biotechnology. 539 Trends Biotechnol.18: 103-107

540

541

542

543

544

545

546

547

548

549

550

551

552

553

554

555

556

557

558

559

560

561

562

563

564

565

566

567

568

569

570

571

572

573

574

575

576

577

578

579

580

581

582

583

584

585

586

10. Gomez-puyou. A., 1992. Biomolecules in organic solvent. U. S. A. CRC Press.

11. Hiol, A., Jonzo, M.D., Druet, D., Comeau, L., 1999. Production, purification and characterization of an extracellular lipase from Mucor hiemalis f. hiemalis. Enzyme Micr. 25: 80-87.

12. Jaeger, K.E., Dijkstra, B.W., Reetz, M.T., 1999. Bacterial biocatalysts: Molecular biology, three dimensional structures, and biotechnological applications of lipases. Annu Rev Microbiol. 53. 315351

13. Kojima, Y., Kobayashi, M., Shimizu, S., 2003. A novel lipase from Pseudomonas fluorescens HU380: gene cloning, overproduction, renaturation-activation, two-step purification, and characterization. J Biosci Bioeng. 96(3): 242-249

14. Kwon, D. Y. and Rhee, J. S., 1986. A simple and rapid colorimetric method for determination of free fatty acids for lipase assay. J Am Oil Chem Soc. 63(1): 89-92

15. Laemmli, U.K., 1970. Cleavage of structural proteins during the assembly of the head of bacteriophage T4. Nature 227: 680-685

16.Lanser, A.C., Manthey, L.K., Hou, C.T., 2001. Regioselectivity of new bacterial lipases determined by hydrolysis of triolein. Curr Microbiol. 44 (5) : 336-340

17. Lu, M., Wang, S., Fang, Y., Li, H., Liu, S., Liu, H., 2010. Cloning, expression, purification and characterization of cold-adapted $\alpha$-amylase from Pseudoalteromonas arctica GS230. Protein J. 29: 591-597

18. Leow, T. C., Rahman, R. N. Z. R. A., Basri, M., and Salleh, A. B., 2007. "A thermoalkaliphilic lipase of Geobacillus sp. T1," Extremophiles, vol. 11, no. 3, pp. 527-535,

19. Margesin, R., Gander, S., Zacke, G., Gounot, A. M., Schinner, F., 2003. Hydrocarbon degradation and enzyme activities of cold-adapted bacteria and yeasts. Extremophiles . 7:451-458

20. Persson, M., Mladeoska, I., Wehtje, E., Adlercreutz, P., 2002. Preparation of lipases for use in organic solvents. Enzym. Microb. Techn. 31: 833-841

21. Rashid, N., Shimada, Y., Ezaki, S., 2001. Atomi H. Imanaka T. Low-temperature lipase from psychrotrophic Pseudomonas sp. Strain KB700A. Appl Environ Micro. 67(9): 4064-4069

23. Rahman, R.N.Z.R.A., Baharum, S. N., Basri. M., Salleh, A. B., 2005. High-yield puriWcation of an organic solvent-tolerant lipase from Pseudomonassp. strain S5. Anal. Biochem. 341 (2005) 267274

24. Raussens, V., Ruysschaert, J.M., Goormaghtigh, E., 2003. Protein concentration is not an absolute prerequisite for the determination of secondary structure from circular dichroism spectra: a new scaling method. Anal Biochem. 114-21 
587

588

589

590

591

592

593

594

595

596

597

598

599

600

601

602

603

604

605

606

607

608

609

610

611

612

613

614

615

616

617

618

619

620

621

622

623

624

625

626

627

628

629

630

631

632

633

25. Rosenau, F., Jaeger, K.E., 2000. Bacterial lipases from Pseudomonas: regulation of gene expression and mechanisms of secretion. Biochimie. 82: 1023-1032.

26. Samad, M.Y.A., Razak, C.N.A., Salleh, A.B., Yunus, W.M.Z.W., Ampon, K. and Basri, M., 1989. A plate assay for primary screening of lipase activity. J Microbiol Meth. 9: 51-56

27. Schmidt, M., Larsen, D.M., Stougaard, P., 2010. A lipase with broad temperature range from an alkaliphilic gamma-proteobacterium isolated in Greenland. Environ Technol 31(10):1091-100

28. Schmidt-Dannert C., 1999. Recombinant microbial lipases for biotechnological applications. Bioorgan Med Chem. 7,10: 2123-2130.

29. Scholze, H., Stutz, H., Paltauf, F., Hermetter, A., 1999. Fluorescent inhibitors for the qualitative and quantitative analysis of lipolytic enzymes. Anal. Biochem. 276:72-80.

30. Sharma, R., Soni, S., Vohra, R., Gupta, L. And Gupta, J., 2002. Purification and characterization of a thermostable alkaline lipase from a new thermophilic Bacillus sp. RSJ-1. Process Biochem.37: 10751084.

31. Sugihara, A., Shimada, Y., Tominaga, T., 1991. A novel Geotrichum candidum lipase with some preference for the 2-position on a triglyceride molecule. Appl Microbiol Biotechnol. 35(6):738-740.

32. Tanaka, J., Nihira, T., Yamada, Y., 2000. Glutathione as an essential factor for chaperon-mediated activation of lactonizing lipase (LipL) from Pseudomonas sp. 109. J Biochem. 127(4):597-601.

33. Verma, N., Thakur, S., Bhatt, A.K., 2012. Microbial Lipases: Industrial Applications and Properties. Int J Biol Sci. 1(8), 88-92

34. Xuebing, X., 2000. Production of specific-structured triacylglycerols by lipase-catalyzed reactions: a review. Eur J Lipid Sci Tech. 2000; 287-303

35. Yan, J., Yang, J., Xu, L., Yan, Y., 2007. Gene cloning, overexpression and characterization of a novel organic solvent tolerant and thermostable lipase from Galactomyces geotrichum Y05. J Mol Catal BEzym. 49:28-35.

36. Zhang, A., Gao, R., Diao, N., Xie, G., Gao, G., Cao, G., 2009. Cloning, expression and characterization of an organic solvent tolerant lipase from Pseudomonas fluorescens JCM5963. J Mol Catal B-Enzym. 56: 78-84

37. Zhang, A., Gao, R., Diao, N., Xie, G., Gao, G., Cao, G., 2009. Cloning, expression and characterization of an organic solvent tolerant lipase from Pseudomonas fluorescens JCM5963. J Mol Catal B-Enzym. 56: $78-84$

38. Zhang, A., Wei, J., Lin, S., Zeng, R.Y., 2007. Cloning, expression and characterization of a coldadapted lipase gene from an Antarctic deep-sea psychrotrophic bacterium, Psychrobacter sp. 7195. J Microbiol Biotechn. 17(4): 604-610 
634 39. Zheng, Y. Y., Guo, X. H., Song, N. N., Li. D. C., 2011. Thermophilic lipase from Thermomyces 635 lanuginosus: Gene cloning, expression and characterization. J. Mol. Catal. B: Enzym. 69 (2011) 636 127-132.

637

638 40. Zheng, X., Chu, X., Zhang, W., Wu, N., Fan, Y., 2011. A novel cold-adapted lipase from Acinobacter 639 sp. XMZ-26: gene cloning and characterization. Appl Microbiol Biot. 90: 971-980

640 
Figure 1 (on next page)

Alignment of the AMS3 lipase sequence.

Fig 1: Alignment of the AMS3 lipase sequence with Pseudomonas lipases of known threedimensional structure. The AMS3 was aligned with $P$. aeruginosa lipase (Q9L6C7),P. fragi lipase (AY787823), G. bacillus T1 (AY166603) and Proteus sp. K107. - =Serine Pentapeptide, $@=$ Aspartic acid and ${ }^{\wedge}=$ Amino acid involve in calcium binding. $(*)$ blue: Conserved residue; (:) green: conservation of strong groups; (.) blue: conservation of weak groups 
AMS_lipase

chain_A_t1

pseudomonas_fragi

pseudomonas_arg_Q9L6C7

proteus_sp $\bar{k} 107$

pseudomonas_flo

AMS_lipase

chain_A_t1

pseudōnonas_fragi

pseudomonas_arg_Q9L6C7

proteus_sp_k 107

pseudomonas flo

AMS_lipase

chaín A t1

pseudomōnas_fragi

pseudomonas_arg_Q926C7

proteus_sp_k̄107

pseudomonas_flo

AMS_lipase

chain_A_t1

pseudomonas_fragi

pseudomonas_arg_Q9L6C7

proteus_sp_k107

pseudomonas_flo

AMS_lipase

chain_A_t1

pseudomonas_fragi

pseudomonas_arg_Q9L6C7

proteus_sp_ $\bar{k} 107$

pseudomonas_flo

AMS_lipase

chaīn_A_t1

pseudōmōnas_fragi

pseudomonas_arg_Q9L6C7

proteus_sp_ $\bar{k} 107$

pseudomonas_flo

AMS_lipase

chain A t1

pseudomonas_fragi

pseudomonas_arg_Q9L6C7

proteus_sp_ki 107

pseudomonas_flo
-

---

----------------------------------------MDDSVN

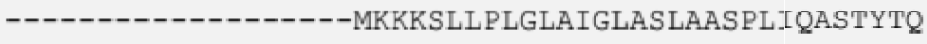

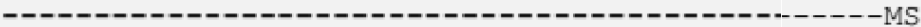

METGI FDYKNLGTEGSKTLFADAMETAITLYSYHNLDNGF'AVGYQHNGLG

NDAPIVLLHGETGWGREE--MFGFKYWGGVRGDIEQWLNDNGYRTYTLAV NDAP IVLLHGETGWGREE--MFGFKYWGGVRGDIEQWLNDNGYRTYTLAV TRYPILLVHGLFGED--R--IGSHHYFHGIK----QALNECGASVEVPI I TKYP IVLAHGMLGED--N--ILGVDYWEGIP----SALRRDGAQVYVTEV TKYPIVLVHGLAGFN--E--IVGFPYFYGIA----DALRQDGHQVETASL LGLPATLVGALLGSTDSQGVIPGIPWNPDSEKAALEAVQKAGWTPISASA

GPLSSNWDRACEAYAQLVGGTVDYGAAHAAKHGHARFGRTYPGLLPELKR GPLSSNWDRACEAYAQLVGGTVDYGAAHAAKHGHARFGRTY PGLLPELKR

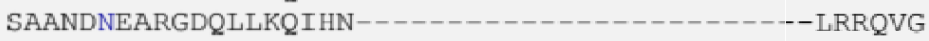

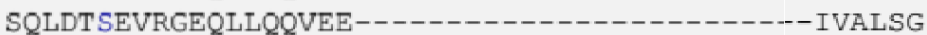
SAFNSNEVRGKQLWQFVQT-----------------------LLQETQ LGYAGKVDARGTFFGEKAGYTTAQVEVLGKYDDAGKLLEIGIG--FRGTS

GGR I H I IAHSQGGQTARMLVSLLENGSQEERE------YAKAHNVSLSPL GGR I H I I AHSQGGQTARMLVSLLENGSQEERE------YAKAHNVSLSPL AQRVNLIGHSQGALTARYVAA IAP---------------------QPKVNLIGHSHGGPTIRYVAAVRP-----------------------

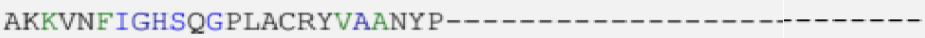
GPRETLISDS IGDLISDLLAALGPKDYAKNYAGEAFGGLLKNVADYAGAH : : $^{*}$.* $^{*} \quad \mathrm{i}, \mathrm{i}$

FEGGHHFVLSVTTIATPHDG------------TTLVNMVDFTDRFED FEGGHHFVLSVT'T I ATPHDG------------- TTLVNMVDFT DRFFD -----ELIASVTSVSGPNHG--------------SELADRLRLAFVPGR -----DLI ASATSVGAPHKG-------------SDTADFLR-QIPPGS -----DSVASVTS INGVNHG--------------SEIADL YRRIMRKDS GLTGKDVVVSGHSLGGLAVNSMETADLSNYKWAGEYKDANYVAYASPTQS

$$
\text { . * : : . . }
$$

LQKAVLEAAAVASNVPYTSQVYDEKLDQWGLRRQPGE-SFDHYFERLKRS LQKAVLEAAAVASNVPYTSQVYDFKLDQWGLRRQPGE-SFDHYEERLKRS LGETVAAALTTSFSAFLSALSGHPRLPQNALNALNAL-TTDGVAAFNRQY AGEAI LSGLVNSLGALI SFLSSGSTGTQNSLGSLESL-NSEGAAARFNAKY I PEY IVEKVLNAFGTI ISTFSGHRGDPQDA IAALESL-TTEQVTEFNNKY AGDKVLNIGYENDPVFRALDGSSFNLSSLGVHDKPHESTTDNIVSENDHY

$$
\text { . : . : : . . }
$$

PVWTSTDTARYDLSVSGAEKLNQWVQASPNTYYLSESTERTYRGALTGNH PVWTSTDTARYDLSVSGAEKLNQWVQASPNTYYLSFSTERTYRGALTGNH PQGLPDRWG-----GMGPAQVN-------AVHYYSWS------GI IKGSR PQGIPTSAC-----GEGAYKVN-------GVSYYSWS----------GSPQALPKTPG-----GEGDEIVN-------GVHYYCFG-------SYIQGLI ASTLWNVLP------FS IVNLPTWVSHLPTAYGDGMETTRI LESGFYDQM 


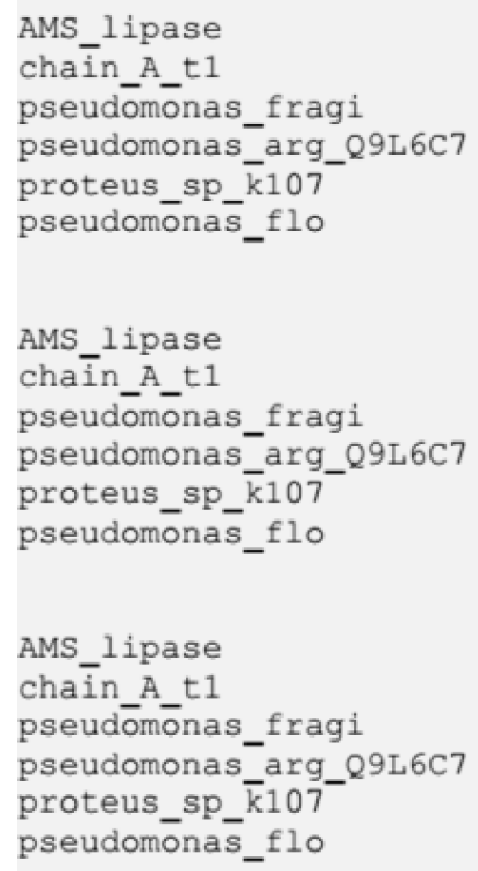

YPELGMNAFSAVVCAPELGSYRNPTLGIDDRWLENDGIVNTVSMNGPKRG YPELGMNAFSAVVCAPELGSYRNPTLGIDDRWLENDGIVNTVSMNGPKRG LAESLN------LLDPLHNALRVEDSFFTRETRENDGMVGRFSSH-----SPLTN------ELDPSDAFLGASSLTFKNGT-ANDGLVGTCSSH----AGEKGN------LLDPTHAAMRVLNTFFTEKQ--NDGLVGRSSMR----ETTRDSTVIVANLSDPARANTWVQDLNRNAEPHKGNTEI I GSDGNDLIQG . $\star *$ : : : . .

SSDRIVPYDGTLKKGVWNDMGTYNVDHLEI IG----VDPNPSFDIRAFYL SSDRIVPYDGTLKKGVWNDMGTYNVDHLE I IG----VDPNPSEDIRAFYL ---------LGQVIRSDYPL DHLDTINHMA----RGSRRRINPVELY I --------LGMVIRDNYRMNHLDQVNQVFG---LTSLFETSPVSVYR ----------LGKLIKDDYAQDH IDMVNQVAG---LVG-YNEDIVAIYT GNGADE IEGGKGNDTIRDNSGHNTELESGHFGNDRVIGYQPTDKLVFKDV : . :

RLAEQLASLRP------

RLAEQLASLQP----------

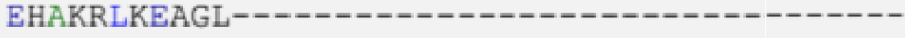

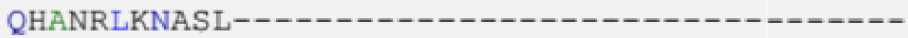

QHAKYLASKQL-------------------------------

QGSTDLRDHAKVVGADTVLTFGADSVTLVGVGHGGLWTEGVVIG . : * . 
Figure 2 (on next page)

Polyacrylamide gel

Fig 2: Polyacrylamide gel electrophoresis (PAGE) profile of recombinant AMS3 lipase. Lane; Lane 1 : Crude lipase; Lane 2: Protein molecular weight marker(Fermentas, Germany); Lane 3: Purified AMS3 lipase ; Homogeneity of AMS3 lipase was determined via native PAGE (Lane 4).The mobility of the purified lipase was estimated around $\sim 60 \mathrm{kDa}$ (indicated by arrow). The protein loaded was approximately around $13 \mu \mathrm{g}$. 


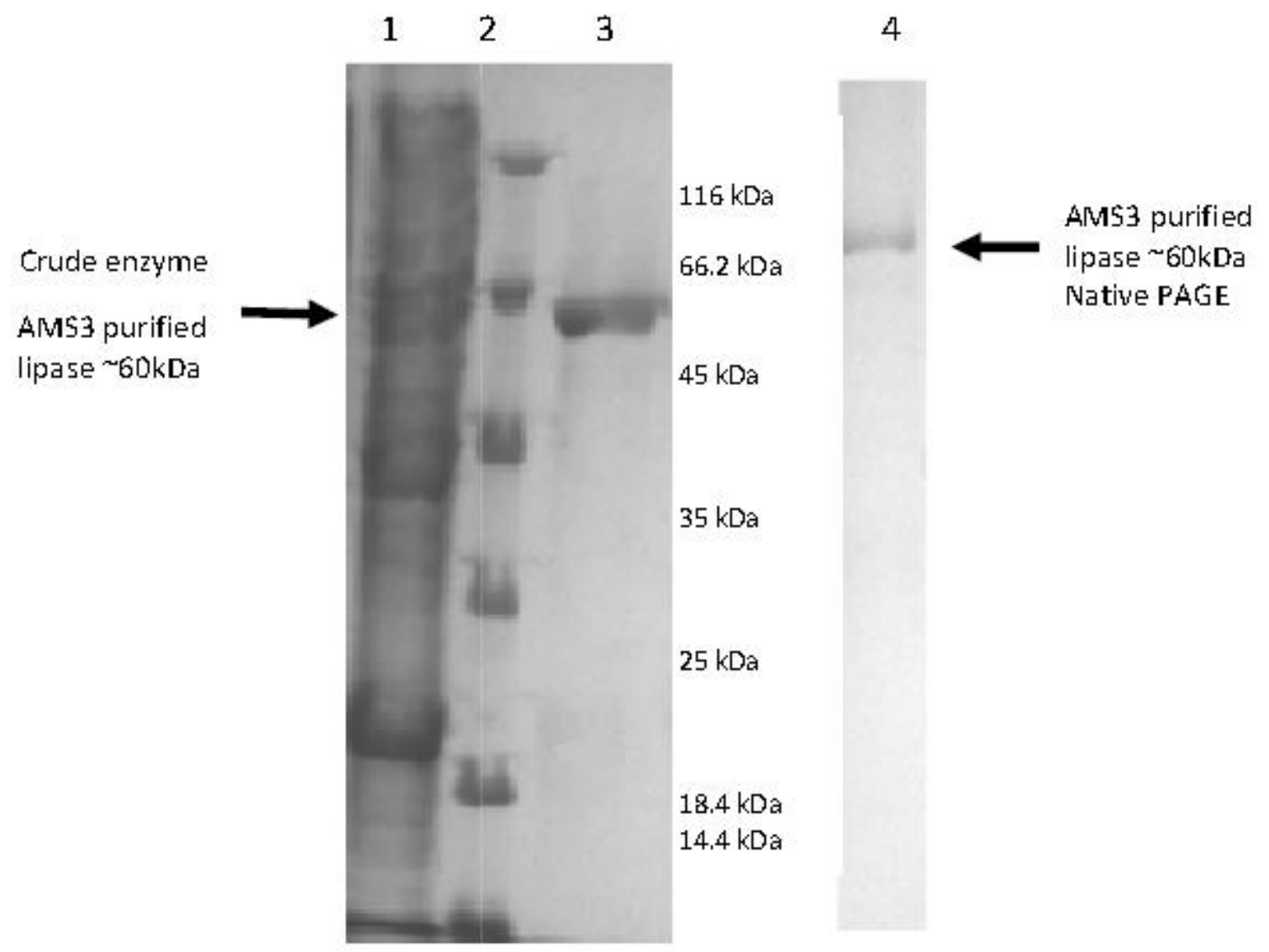




\section{Figure 3 (on next page)}

\section{Effect of temperature}

Fig 3: Effect of temperature on purified AMS3 lipase activity. The lipase assay was done using olive oil as a substrate. (A). Enzyme samples were assayed at various temperatures as mentioned in the Methods section. The temperature that showed the highest lipase activity was considered to be the optimum temperature for the AMS3 lipase. The effect of temperature on purified AMS3 lipase stability (B). Enzyme stability was tested at different temperature. The enzyme was incubated at various temperatures in $30 \mathrm{~min}$. The assay was performed at optimum temperature. The relative activity was calculated using $30^{\circ} \mathrm{C}$ as $100 \%$. 

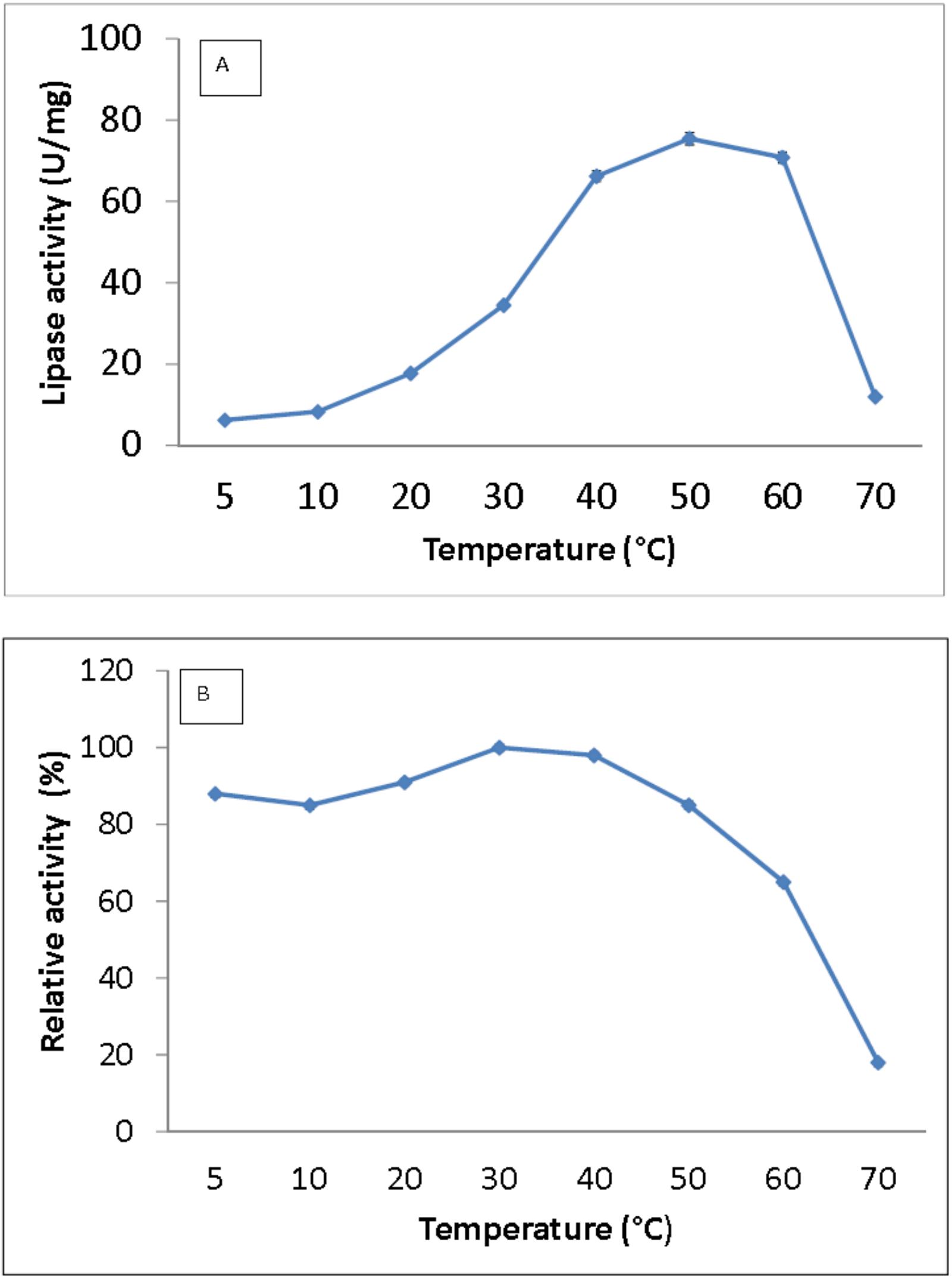
Figure 4(on next page)

Effect of $\mathrm{pH}$

Fig 4: Effect of pH on purified AMS3 lipase activity (A). The lipase activity was measured at different $\mathrm{pH}$ using olive oil emulsion as substrate and assay at $50{ }^{\circ} \mathrm{C}$ for $30 \mathrm{~min}$. Effect of $\mathrm{pH}$ on purified AMS3 lipase stability is shown in figure (B). The enzyme was pre-incubated at different buffer for $30 \mathrm{~min}$. The lipase assay was performed at $50{ }^{\circ} \mathrm{C}$. Sodium acetate buffer was used for the $\mathrm{pH}$ range of 4.0 to $6.0($ ); potassium phosphate buffer for the $\mathrm{pH}$ range of 6.0 to $8.0(\mathbf{\square})$; Tris- $\mathrm{HCl}$ buffer for the $\mathrm{pH}$ range of 8.0 to $9.0(\mathbf{\Lambda})$; and glycine- $\mathrm{NaOH}$ buffer for the $\mathrm{pH}$ range of 9.0 to 12.0 . $(\mathrm{x})$. The relative activity was measure using $\mathrm{pH} 7$ as $100 \%$. 

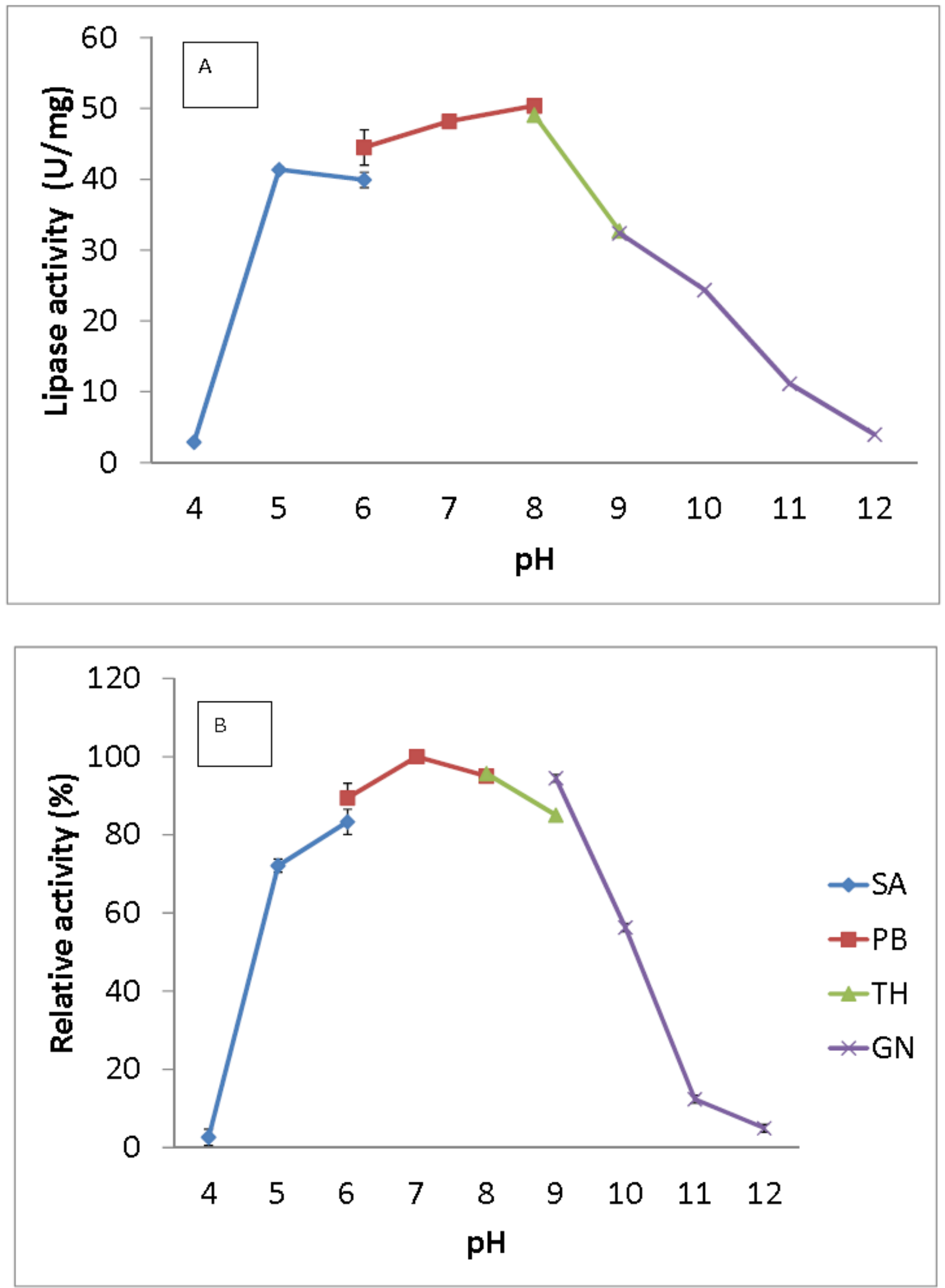
Figure $\mathbf{5}$ (on next page)

Effect of metal

Fig 5: Effect of metal ions on AMS3 lipase stability. All assay was done using olive oil as substrate. The enzyme was pre-incubated at $50{ }^{\circ} \mathrm{C}$ with various metal ions at concentrations of $1 \mathrm{mM}$ (blue) and $5 \mathrm{mM}$ (red). The treated enzyme was assay at $50{ }^{\circ} \mathrm{C}$ for $30 \mathrm{~min}$. The untreated enzyme was considered as a control or $100 \%$. 


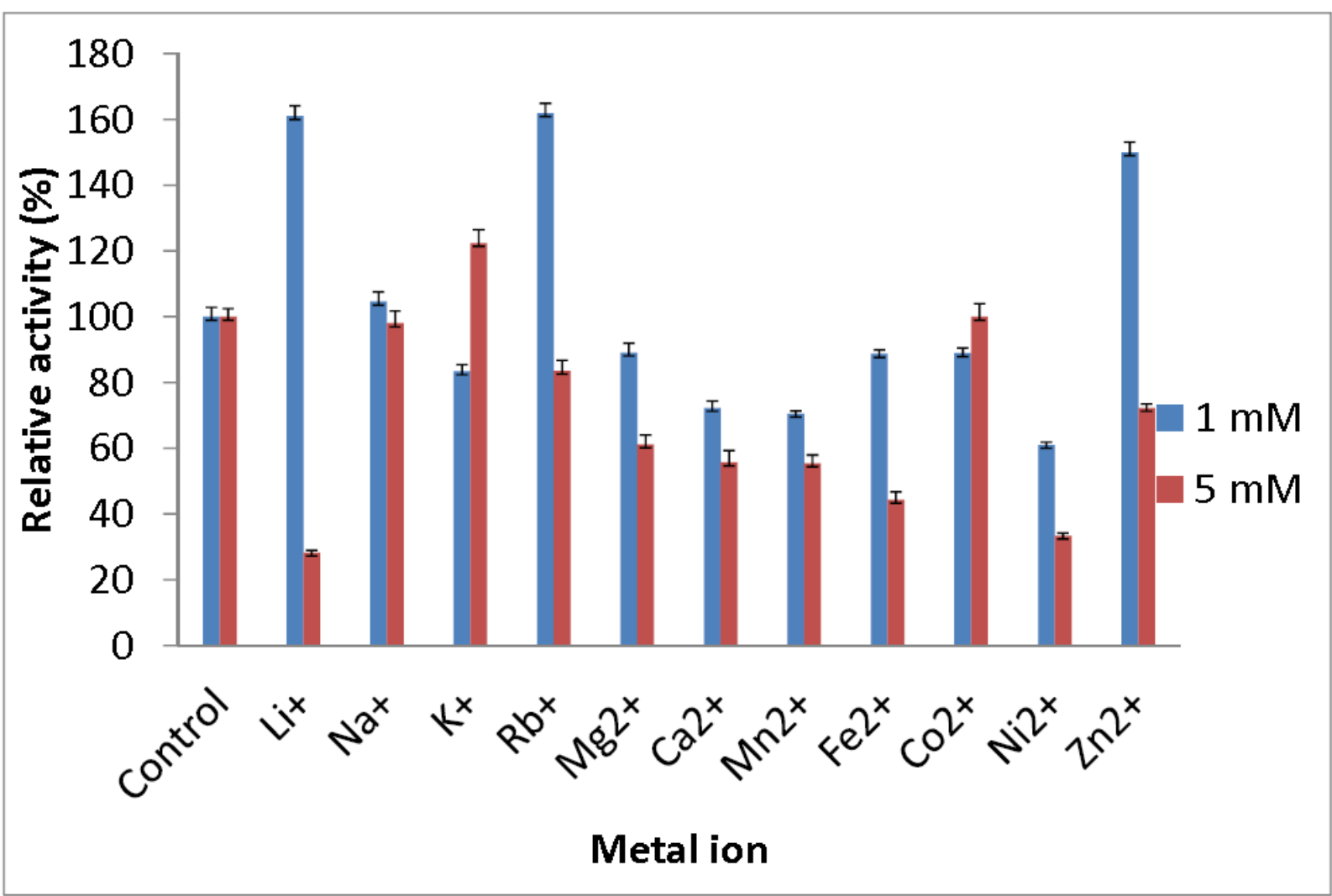


Figure 6 (on next page)

Substrate specificity

Fig 6: Substrate specificity of purified AMS3 lipase toward natural oil. The assay was performed at $50^{\circ} \mathrm{C}$ for $30 \mathrm{~min}$. Substrate emulsion prepared with various natural oil with ratio 1:1 (buffer and natural oil). Data shown are the means from triplicate measurements expressing \% activity relative to that with olive oil . 


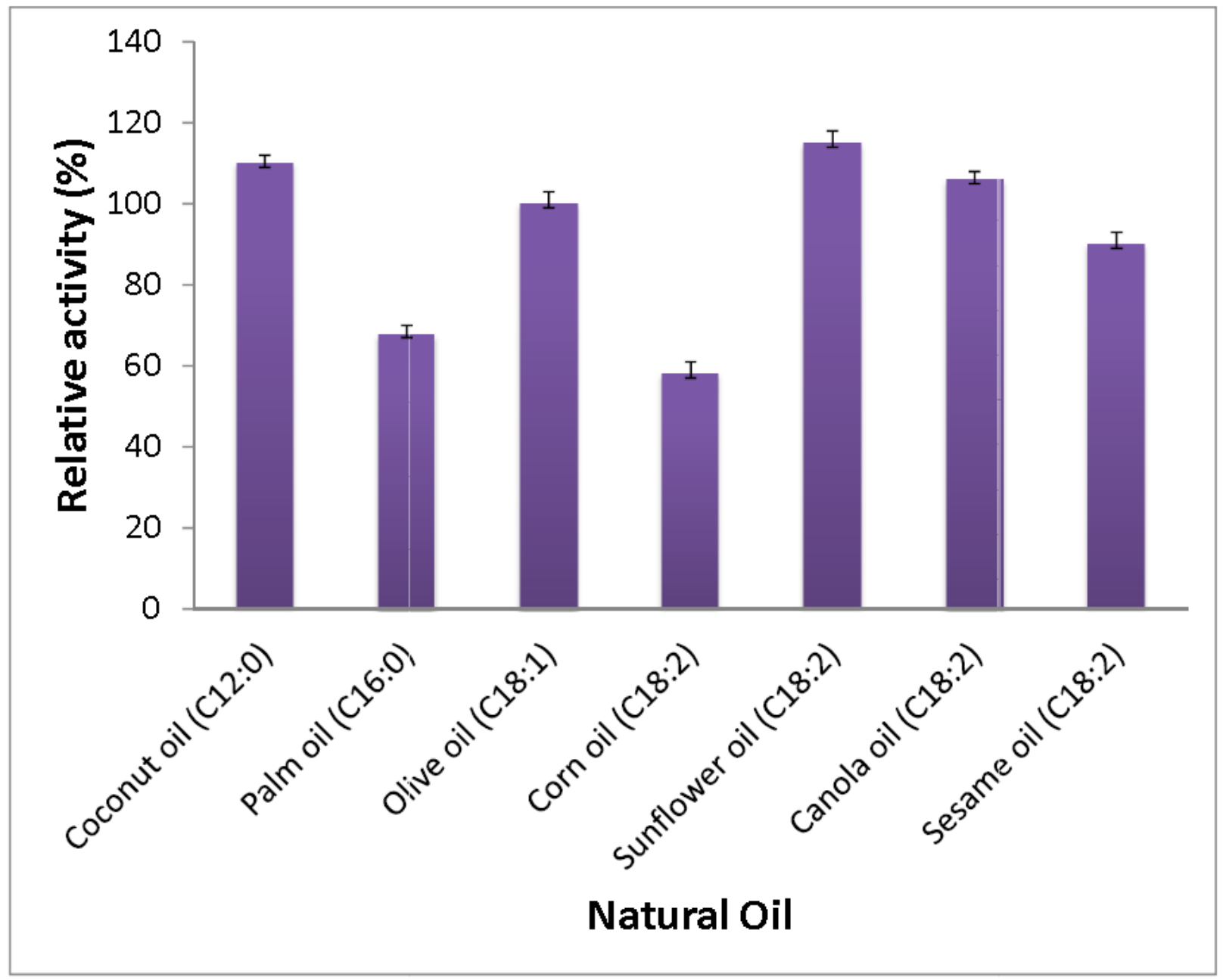




\section{Figure 7 (on next page)}

\section{Effect of solvent}

Fig 7: Effect of solvents on purified AMS3 lipase. All the assay was done using olive oil as a substrate. Incubation time for treated enzyme with organic solvent was 30 min and assay at $50^{\circ} \mathrm{C}$. Remaining lipase activity was expressed relative to that of the control (without solvent). Log P (water/octanol coefficient) value of each solvents are represented in parenthesis. 


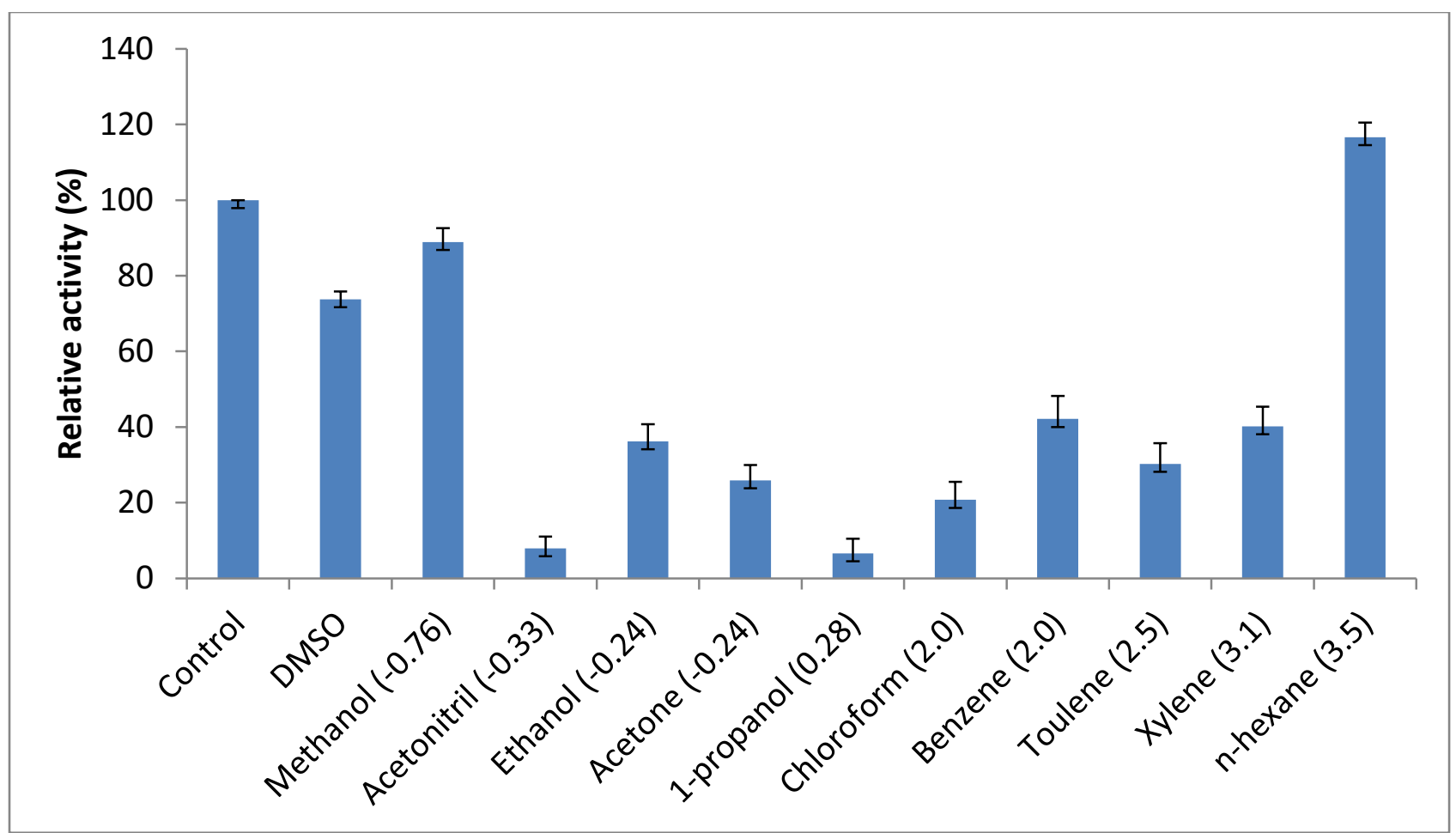


Figure 8 (on next page)

AMS3 lipase melting point

Fig 8: AMS3 lipase melting point and secondary content determination. Vertical line (arrow) indicating the melting point value of AMS3 lipase when tested from temperature ranging from $10-90^{\circ} \mathrm{C}$. (Figure 8A). Changes on the secondary structure content of AMS3 lipase were notably observed as the enzyme was subjected at different temperature (Figure 8B). 

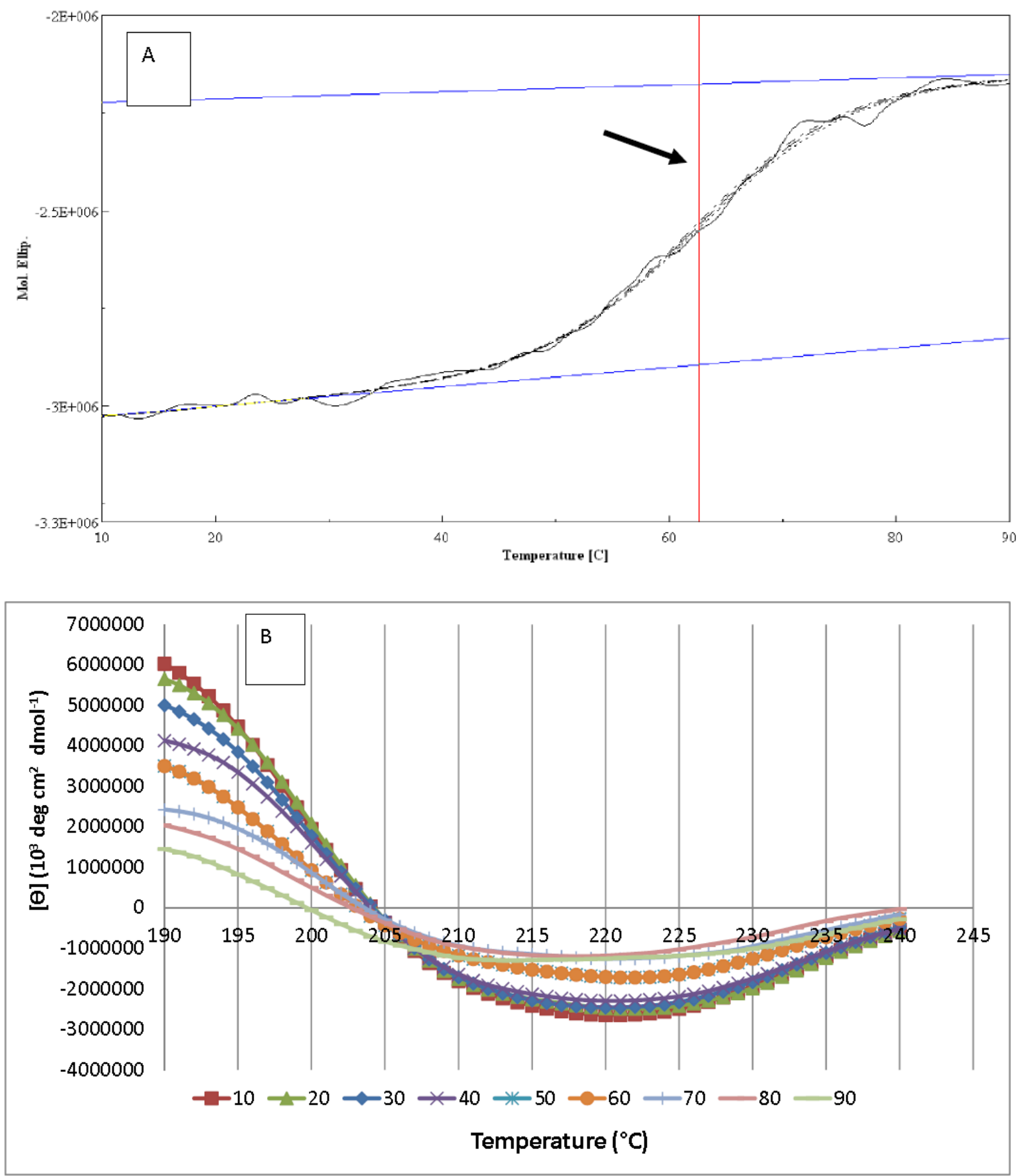